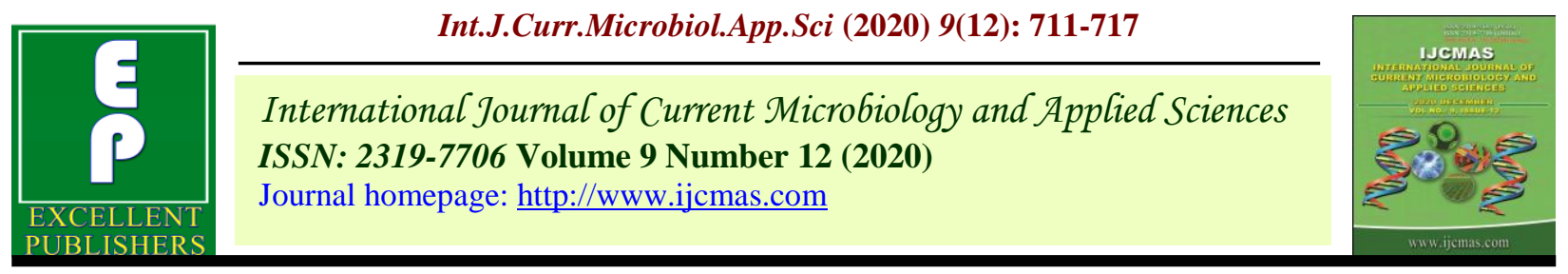

Original Research Article

https://doi.org/10.20546/ijcmas.2020.912.085

\title{
Assessment of Soil Health of Different Blocks of Samastipur, Bihar by Root Health Bio Assay Test
}

\author{
Kumari Sushma Mahto* and Dinesh Rai \\ Department of Plant Pathology, Dr. Rajendra Prasad Central Agricultural University, Pusa, \\ Samastipur, Bihar, India \\ *Corresponding author
}

\section{A B S T R A C T}

\section{Keywords}

Soil health, Root health bio assay test, Plant growth promotion, $\mathrm{pH}$, Organic carbon

\section{Article Info}

Accepted:

07 November 2020

Available Online:

10 December 2020
A study was undertaken to explore and analyze the soil health of different blocks of Samastipur. Five soil samples from each cultivated and uncultivated fields were collected from different villages of Samastipur namely Deopar (Block- Pusa), Motipur (BlockTajpur), Aadharpur (Block- Tajpur), Dudhpura (Block- Samastipur) and Dadpur (BlockSamastipur) and different physico-chemical properties were assessed. Root health bioassay test was also performed in pots under greenhouse conditions. The soil of Deopar and Dadpur of both cultivated and uncultivated soil samples showed best ratings among the tested all the soil samples. In growth promotion study, overall plant growth promotion was better in cultivated fields soil samples compared to uncultivated fields. Maximum root length $(13.0 \mathrm{~cm})$ was observed in Motipur; shoot length $(62.6 \mathrm{~cm})$ in Deopar; root weight $(18.3 \mathrm{~g})$ in Dadpur and maximum shoot weight $(44.0 \mathrm{~g})$ Aadharpur in cultivated fields. The soil samples of both cultivated and uncultivated fields were assessed on the different parameters i.e. soil texture, $\mathrm{pH}$, organic carbon and organic matter. The results revealed that, $\mathrm{pH}$ ranging from 7.2 to 8.2 and 7.4 to 7.9 in cultivated and uncultivated fields respectively. Maximum organic carbon $(0.69 \%)$ and organic matter $(1.18 \%)$ observed in cultivated fields of Deopar.

\section{Introduction}

Soil quality is proportional with the soil functions such as it is providing a medium for the proper plant growth and development, furnishing the supply of water and storage of nutrients. Soil functions are an amalgamation of several activities such as decomposition of organic matter, nutrient cycling, storage of water and its release, and the regulation of naturally present biological soil population (Ritz et al., 2009).
These soil indicators are dynamic properties and are very much sensitive and affecting in nature to the management of land, occurring natural interferences and presence of chemical contaminants in the soil. Soil health is the potentiality of the soil to perform as an important living body of soil with the integration of ecosystem and the use of land energy for the maintenance of biological or living productivity, quality of environment, and the promotion of total health of all living biota of lithosphere (Doran and Zeiss, 2000). 
The healthy soil must having many properties to sustain a wide variety of microflora within it like high water retention, high amount of organic matter, good tilt and aeration, good drainage, adequate supply of nutrients, suitable depth for the root growth, diversified microflora and microfauna, resistant to soil degradation process and able to overcome adverse conditions (Magdoff, 2001).

Root health analysis by the bio assay test and its assessment is a method which is used to determine the soil health by examination of the quality of roots which is determined by its colour, length, texture, and the absence of any sort of sign and symptoms of pathogen attack by the various soil borne fungi like Fusarium, Pythium, Colletotrichum etc. and different crop parasitic nematodes.

\section{Materials and Methods}

The present investigation was carried out in the Department of Plant Pathology and Department of Soil Science, PG College of Agriculture, Dr. Rajendra Prasad Central Agricultural University, Pusa, Samastipur, Bihar.

\section{Collection sites}

The soil samples were collected from five different villages i.e. Deopar, Motipur, Aadharpur, Dudhpura and Dadpur of three blocks i.e. Pusa, Tajpur and Samastipur of Samastipur, Bihar during August 2019 to September 2019 and fields selected were cultivated and uncultivated.

In agricultural field, soil samples were collected from the root zone proximity where, most of the microbial population is found concentrated. Each sample bag was labelled appropriately by indicating the detailed site of collection, cropping system followed, sample type and date. The collected samples were brought to the laboratory and preserved at safe and cool place for the further studies.

\section{Root Health Bio Assay Test}

The experiment was conducted in the greenhouse of RPCAU, Pusa, Samastipur. The plastic pots ( $2 \mathrm{~kg}$ capacity) filled with respective soil samples collected from different villages of Samastipur. A total of 10 soil samples from 5 different villages are filled in pots which have cotton balls placed in the bottom to prevent soil loss through the drainage holes. The seeds of bean variety Green Komal were sowed in each pot (5 in no.).The hilum i.e. curved side of the bean is placed flat, to uplift the successful emergence and seed germination. The plants were maintained in the greenhouse under supplemental light and watered regularly for 6 weeks. The temperature of Greenhouse chamber was maintained at $25^{\circ} \mathrm{C}$. The experiment was laid out in a Completely Randomized Design (CRD) with three replications. The ten soil samples were imposed as ten treatments. The plants were removed carefully after 6 weeks for root health assessment and analysis. The Rating scale for root health test was done as per (Add on Test, 2017) and rated as described below in Table 1. Plant growth promotion of various parameters was also studied in the test. Observations on root (length and weight) and shoot (length and weight) were recorded to analyse the overall growth promotion potential in different soil samples.

\section{Biological Indicators of Soil Analysis}

Soil analysis was done in the laboratory of Department of Soil Science, RPCAU, Pusa, Samastipur. The soil samples were analysed for the soil texture, soil $\mathrm{pH}$, organic carbon (\%) and organic matter (\%) content by following the standard procedure. 


\section{Soil texture}

Soil texture was analysed by the soil rapid feel method (Prasad et al., 2006). The samples were designated to the textural class as described in Table 2.

\section{Soil pH}

Ten grams of properly air-dried and finely sieved soil was taken in a beaker of $100 \mathrm{ml}$. $20 \mathrm{ml}$ of distilled water was added into it. The suspension prepared was left for half an hour with swirling in between. The $\mathrm{pH}$ of the suspension was derived by the use of $\mathrm{pH}$ meter.

\section{Soil organic carbon}

Organic carbon percentage of the soil was calculated by the Walkley's and Black's method (1934).

\section{Results and Discussion}

\section{Analysis of roots by morphological and visual inspection}

Root health assessment was done by using the root health scale and visual inspection. The roots of bean pulled out carefully after 6 weeks and analysed morphologically and visually (Fig. 1). The results revealed that in overall rating, Deopar and Dadpur village's soil samples showed good soil health in both cultivated \& uncultivated fields and rated as 2. Motipur, Aadharpur and Dudhpura villages soil samples rated similar in both cultivated and uncultivated fields.

However, soil samples collected from uncultivated fields in Dudhpura village rated as poor soil health in all the parameters (Table $3)$. The work was in accordance with Abawi et al., (2004) they performed the root health bio assay test using the bean seeds under greenhouse conditions, maintained the plant for 6 weeks in greenhouse and after the completion of the research they studied the roots for any prominent sign of pathogen infestation.

Oyarzun (1993) performed a bio-assay test of roots by using pea in pots under greenhouse conditions. They recorded the severity of root rot and they rated the roots on a scale of 0 to 5 on the basis of root symptoms.

\section{Analysis of the plant growth promotion potential of cultivated and uncultivated fields}

All the soil samples of both cultivated and uncultivated fields were evaluated in pot under greenhouse conditions for the analysis of plant growth promotion. The results (Table 4) revealed that overall plant growth promotion was good in cultivated compare to uncultivated fields. Significant maximum root length $(13.0 \mathrm{~cm})$ was observed in cultivated field of Motipur while in uncultivated fields of Deopar (10.3) and Dadpur $(10.3 \mathrm{~cm})$.

Maximum shoot length was observed in cultivated fields $(62.6 \mathrm{~cm})$ and uncultivated fields of Deopar $(55.3 \mathrm{~cm})$. Significant maximum root weight $(18.3 \mathrm{~g})$ and $(15.6 \mathrm{~g})$ recorded in cultivated and uncultivated fields of Dadpur respectively. However, maximum shoot weight $(44.0 \mathrm{~g})$ in cultivated and $(42.3$ g) in uncultivated fields observed in Aadharpur.

Maduewesi and Lockwood (1976) conducted root health bio-assay test using soybean and they studied the effect of root rot pathogen on the soybean roots by the growth promotion study. Yadav et al., (2020) in their plant bioassay abbreviated ASURE done by hydroponics. They performed this bio-assay test using sorghum as a host plant. 
Table.1 Rating system in root health bio-assay test (Add on Test, 2017)

\begin{tabular}{|c|c|c|}
\hline S. No. & Rating Scale & Symptoms \\
\hline 1. & 2 & $\begin{array}{l}\text { Roots appear healthy, coarse in texture and having } \\
\text { white hypocotyl. }\end{array}$ \\
\hline 2. & 4 & $\begin{array}{l}\text { Roots show lesions in an area upto } 1 / 10^{\text {th }} \text { of the } \\
\text { hypocotyl, light discolouration of root tissues. }\end{array}$ \\
\hline 3. & 6 & $\begin{array}{l}\text { Roots show lesions in an area upto } 1 / 4^{\text {th }} \text { of the } \\
\text { hypocotyl and root tissues appears hard. }\end{array}$ \\
\hline 4. & $7-9$ & $\begin{array}{l}\text { The higher level of damage and decay varies from } \\
\text { almost } 1 / 2 \text { to } 1 / 3^{\text {rd }} \text { of the hypocotyl and roots show } \\
\text { many abrasion and lesions. Severe sign and symptoms } \\
\text { of pathogen attack visible. }\end{array}$ \\
\hline
\end{tabular}

Table.2 Soil texture classification after analysis of collected soil samples

\begin{tabular}{|l|l|l|l|l|}
\hline \multicolumn{1}{|c|}{ VERY COURSE } & \multicolumn{2}{|c|}{ COURSE } & \multicolumn{2}{c|}{ MEDIUM } \\
\hline \multicolumn{1}{|c|}{ Sand } & Loamy Sand & \multicolumn{1}{c|}{ Sandy Loam } & \multicolumn{1}{c|}{ Loamy } & \multicolumn{1}{c|}{ Silty Loam } \\
\hline $\begin{array}{l}\text { Soil neither } \\
\text { appeared too dry } \\
\text { nor too wet. No } \\
\text { shape formation. }\end{array}$ & $\begin{array}{l}\text { No ribbon } \\
\text { formation } \\
\text { when the } \\
\text { formed ball is } \\
\text { pressed. }\end{array}$ & $\begin{array}{l}\text { Forms ribbon } \\
\text { and feels very } \\
\text { gritty. }\end{array}$ & $\begin{array}{l}\text { Forms ribbon } \\
\text { and feels neither } \\
\text { very gritty nor }\end{array}$ & $\begin{array}{l}\text { Forms ribbon } \\
\text { and feels very } \\
\text { soft and } \\
\text { very smooth. }\end{array}$ \\
\hline
\end{tabular}

Table.3 Characteristics of bean root in root health bio-assay test

\begin{tabular}{|l|l|c|c|c|c|c|c|}
\hline S.No. & \multicolumn{1}{|c|}{ Parameters } & $\begin{array}{c}\text { Sample } \\
\text { Type }\end{array}$ & Deopar & Motipur & Aadharpur & Dudhpura & Dadpur \\
\hline 1. & Overall Rating & C & 2 & 4 & 4 & 4 & 2 \\
\hline 2. & Root Colour & UC & 2 & 2 & 2 & 6 & 2 \\
\hline & & C & Brown & $\begin{array}{c}\text { Dark } \\
\text { Brown }\end{array}$ & Brown & Brown & Dark \\
Brown
\end{tabular}

*C-Cultivated field sample, UC- Uncultivated field sample 
Table.4 Length and weight of bean root and shoot in root health bio-assay test

\begin{tabular}{|l|l|l|l|l|l|l|}
\hline & & \multicolumn{2}{|c|}{ LENGTH $(\mathbf{c m})$} & \multicolumn{2}{c|}{ WEIGHT $(\mathbf{c m})$} \\
\hline S.NO. & VILLAGE & $\begin{array}{l}\text { SAMPLE } \\
\text { TYPE }\end{array}$ & ROOT & SHOOT & ROOT & SHOOT \\
\hline $\mathbf{1 .}$ & Deopar & C & 11.6 & 62.6 & 14.3 & 36.3 \\
\hline $\mathbf{2 .}$ & Motipur & C & 13.0 & 43.6 & 13.6 & 32.6 \\
\hline $\mathbf{3 .}$ & Aadharpur & C & 10.0 & 50.6 & 16.0 & 44.0 \\
\hline $\mathbf{4 .}$ & Dudhpura & C & 10.3 & 49.3 & 17.0 & 36.6 \\
\hline $\mathbf{5 .}$ & Dadpur & C & 12.6 & 55.3 & 18.3 & 38.3 \\
\hline $\mathbf{6 .}$ & Deopar & UC & 10.3 & 55.3 & 13.0 & 35.0 \\
\hline $\mathbf{7 .}$ & Motipur & UC & 9.0 & 43.6 & 13.6 & 28.3 \\
\hline $\mathbf{8 .}$ & Aadharpur & UC & 9.2 & 49.6 & 12.0 & 42.3 \\
\hline $\mathbf{9 .}$ & Dudhpura & UC & 9.0 & 45.0 & 13.3 & 35.6 \\
\hline $\mathbf{1 0 .}$ & Dadpur & UC & 10.3 & 44.6 & 15.6 & 35.0 \\
\hline C.D.(P<0.5) & & & $\mathbf{1 . 3 1 6}$ & $\mathbf{3 . 0 8 0}$ & $\mathbf{1 . 7 9 9}$ & $\mathbf{2 . 1 9 6}$ \\
\hline S.E(m) $\mathbf{\pm}$ & & & $\mathbf{0 . 4 4 3}$ & $\mathbf{1 . 0 3 7}$ & $\mathbf{0 . 6 0 6}$ & $\mathbf{0 . 7 3 9}$ \\
\hline C.V. & & & $\mathbf{7 . 2 8 0}$ & $\mathbf{3 . 5 9 5}$ & $\mathbf{7 . 1 3 5}$ & $\mathbf{3 . 5 1 7}$ \\
\hline
\end{tabular}

$*$ C-Cultivated field sample, UC- Uncultivated field sample *mean of 3 replications

Table.5 Analysis of physico-chemical properties of soil samples

\begin{tabular}{|c|c|c|c|c|c|c|}
\hline $\begin{array}{l}\text { S. } \\
\text { NO. }\end{array}$ & VILLAGE & $\begin{array}{l}\text { SAMPLE } \\
\text { TYPE }\end{array}$ & $\begin{array}{l}\text { SOIL } \\
\text { TEXTURE }\end{array}$ & pH & $\begin{array}{l}\text { ORGANIC } \\
\text { CARBON }(\%)\end{array}$ & $\begin{array}{l}\text { ORGANIC } \\
\text { MATTER } \\
(\%)\end{array}$ \\
\hline \multirow[t]{2}{*}{1.} & \multirow[t]{2}{*}{ Deopar } & $\mathrm{C}$ & Loamy & 8.2 & 0.69 & 1.18 \\
\hline & & $\mathrm{UC}$ & $\begin{array}{l}\text { Sandy } \\
\text { Loamy }\end{array}$ & 7.9 & 0.56 & 0.96 \\
\hline \multirow[t]{2}{*}{2.} & \multirow[t]{2}{*}{ Motipur } & $\mathrm{C}$ & Silty Loamy & 7.3 & 0.47 & 0.81 \\
\hline & & $\mathrm{UC}$ & Loamy & 7.4 & 0.39 & 0.67 \\
\hline \multirow[t]{2}{*}{3.} & \multirow[t]{2}{*}{ Aadharpur } & $\mathrm{C}$ & $\begin{array}{l}\text { Sandy } \\
\text { Loamy }\end{array}$ & 7.5 & 0.37 & 0.63 \\
\hline & & $\mathrm{UC}$ & $\begin{array}{l}\text { Sandy } \\
\text { Loamy }\end{array}$ & 7.8 & 0.32 & 0.55 \\
\hline \multirow[t]{2}{*}{4.} & \multirow[t]{2}{*}{ Dudhpura } & $\mathrm{C}$ & Silty Loamy & 7.2 & 0.27 & 0.46 \\
\hline & & UC & $\begin{array}{l}\text { Sandy } \\
\text { Loamy }\end{array}$ & 7.4 & 0.25 & 0.43 \\
\hline \multirow[t]{2}{*}{5.} & \multirow[t]{2}{*}{ Dadpur } & $\mathrm{C}$ & Silty Loamy & 7.9 & 0.62 & 1.06 \\
\hline & & $\mathrm{UC}$ & Loamy & 7.6 & 0.53 & 0.91 \\
\hline
\end{tabular}

${ }^{*}$ C- Cultivated field sample, UC- Uncultivated field sample 
Fig.1 Roots characteristics after root health bioassay test in village samples

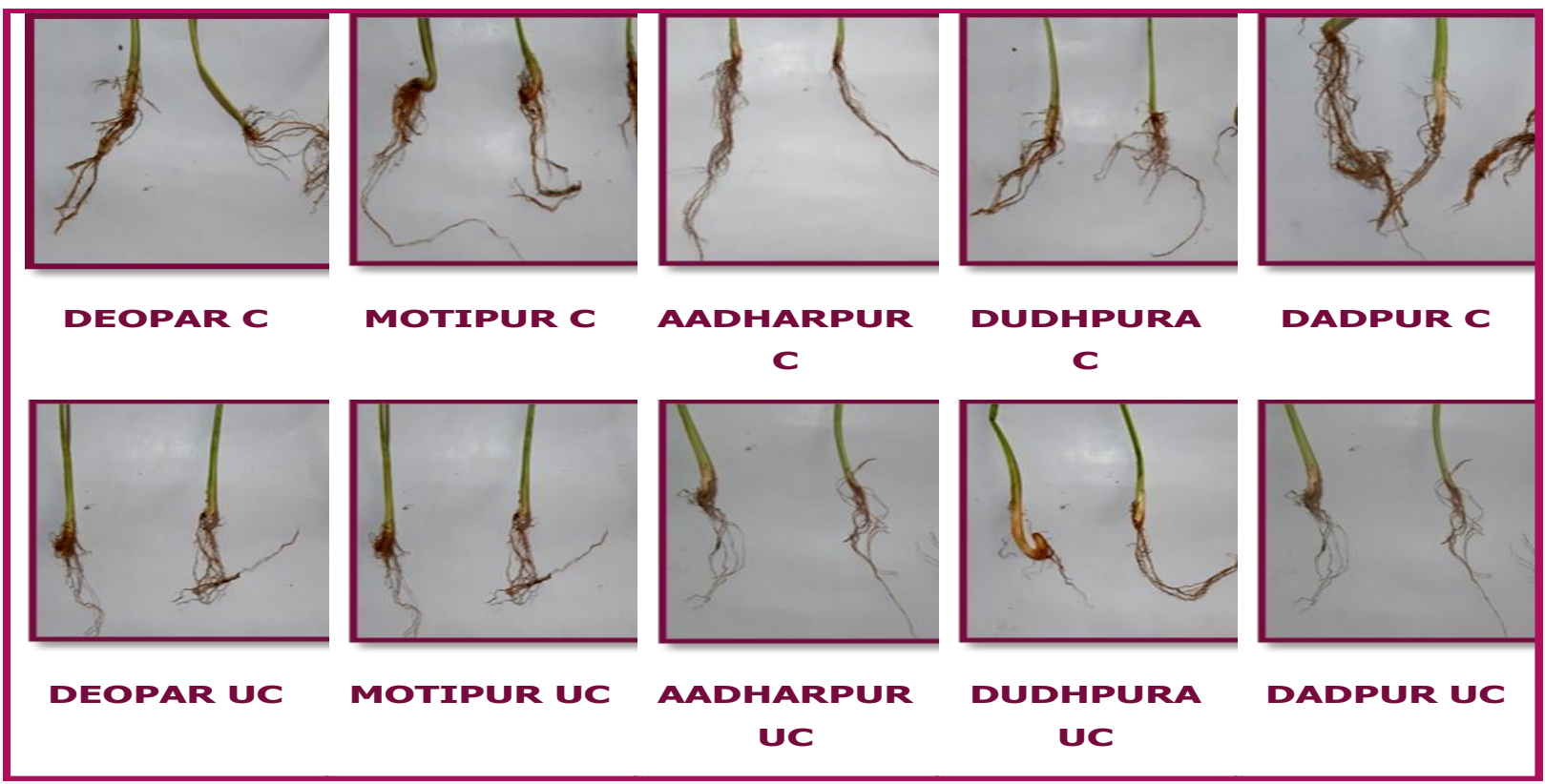

*C- Cultivated Field Sample *UC- Uncultivated Field Sample

Analysis of physico-chemical parameters of the soil

The soil samples of both cultivated and uncultivated fields were assessed on the different parameters i.e. soil texture, $\mathrm{pH}$, organic carbon and organic matter. The results (Table 5) revealed that, $\mathrm{pH}$ ranging recorded from 7.2 to 8.2 and 7.4 to 7.9 in cultivated and uncultivated fields respectively. Maximum organic carbon (0.69 $\%)$ and organic matter $(1.18 \%)$ observed in cultivated fields of Deopar while minimum organic carbon $(0.25 \%)$ and organic matter $(0.43 \%)$ in uncultivated fields of Dudhpura. Sangeetha et al., (2017) reported that maximum fungal diversity was found in the sandy clayey loamy soil. They related various physico - chemical properties of the soil with the fungal population residing there. They explained that the population and diversity of fungi is related with several properties of soil like soil texture. Srivastava et al., (2019) studied the soil samples taken from red gram rhizosphere and studied the diversity of native mycoflora. They studied various soil parameters like soil texture and found that sandy loam soil was most favourable for growth and population of fungi. They also observed that the sandy loam soil was most conducive soil for the profused growth of many soil borne fungi as the sand factor present in the soil keeps aerating the soil which helps the fungal population to easily dessiminate and increase their population in the soil. The $\mathrm{pH}$ of the soil samples varied from 7.2 to 8.2 which indicated that the samples were in alkaline side and no significant influence of soil $\mathrm{pH}$ on the native mycoflora diversity was observed. Accordingly, Senthamilsevi and Victoria (2020) isolated and identified the fungal species from the soil sample of tomato rhizosphere. The study revealed that that $\mathrm{pH}$ range of the soil samples was ranging from 6.6 to 7.2 and the soil $\mathrm{pH}$ properties were not affecting the mycofloral diversity remarkably.

In conclusion the roots grown in the soil of Deopar and Dadpur in both cultivated and 
uncultivated soil samples performed best in various parameters which showed soil of both the villages were having good soil health and least pathogen pressure. The fungal diversity can be directly related to the organic carbon $\%$ as a result. Deopar (Block-Pusa) and Dadpur (Block- Samastipur) can be inferred as best in overall soil health which in turn indicated good soil physical and biological properties.

\section{Acknowledgement}

The experimental findings are the part of post graduate research Programme of the first author of the Department of plant pathology, Dr. Rajendra Prasad Central Agricultural University, Pusa We are very grateful to Dr. R. Laik (Head, Dept. of Soil Science) for providing all the required resources needed during the research period.

\section{References}

Abawi, G. S., Ludwig, J. W. and Petzoldt, C. H. 2004. Assesing root health by a soil bioassay with beans as an indicator of soil health. Phytopathology. 157: 28.

Add-onTest. 2017. Root Health Bio-assay, Soil Health Manual Series Cornell University. Fact Sheet Number. 16-13.

Doran, J. W. and Zeiss, M. R. 2000. Soil health and sustainability: managing the biotic component of soil quality. Appl. Soil Ecol. 15: 3-11.

Maduewesi, J.N.C. and Lockwood, J.L. 1976. Test tube method of bioassay Thielaviopsis basicola root rot of soybean. Phytopathology. 66: 811-814.

Magdoff, F. V. 2001. Concepts, components, and strategies of soil health in agroecosystems. J. Nematol. 33: 169-172.

Oyarzun, P. J. 1993. Bioassay to assess root rot in pea and effect of root rot on yield. Neth. J. Pl. Path. 99: 61-75.

Ritz, K., Black, H. I. J., Campbell, C. D., Harris, J. A. and Wood, C. 2009. Selecting biological indicators for monitoring soils: a framework for balancing scientific opinion to assist policy development. Ecological Indicators. pp. 1212-1221.

Sangeetha, M., Kanimozhi, K., Panneerselvam, A. and Senthilkumar, R. 2017. Studies on Mycoflora Population in Various Irrigated Paddy Field Soil at Thanjavur District. Int.J.Curr.Microbiol.App.Sci. 6(3): 310316.

Senthamelsevi, S. and Victoria, J. 2020. Studies on Physicochemical and Population Dynamics of Mycoflora in Lycopersicum esculentum Rhizosphere Soil Sample from Thanjavur District. Journal of Information and Computational Science. 10(2): 980988.

Srivastava, M. P., Yadav, N., Kannaujia, P., Awasthi, K. and Sharma, Y. K. 2019. Relationship between Mycoflora and Soil Functionality in Pigeon Pea (Cajanus cajan L.) in some Districts of Uttar Pradesh, India. International Journal of Plant and Environment. 5(2): 125-131.

Yadav, P., Kumari, A., and Sundari, S. K. 2020. "ASURE": A multi-potential plant bioassay as a pre-determinative microbial efficiency testing tool for bioinoculant studies. Methods X. 7. pp. 1-14.

\section{How to cite this article:}

Kumari Sushma Mahto and Dinesh Rai. 2020. Assessment of Soil Health of Different Blocks of Samastipur, Bihar by Root Health Bio Assay Test. Int.J.Curr.Microbiol.App.Sci. 9(12): 711717. doi: https://doi.org/10.20546/ijcmas.2020.912.085 